\title{
PATHOLOGICAL AND BACTERIOLOGICAL STUDIES ON SOME RECORDED INTERNAL ABSCESSES IN SLAUGHTERED CATTLE
}

\author{
WALAA F. AWADIN ${ }^{1}$ and AMAL AWAD ${ }^{2}$ \\ ${ }^{1}$ Pathology Department, Faculty of Veterinary Medicine, Mansoura University \\ ${ }^{2}$ Department of Bacteriology, Mycology and Immunology, Faculty of Veterinary Medicine, Mansoura \\ University, Mansoura, Egypt
}

Received: 16 November 2016; $\quad$ Accepted: 19 December 2016

\begin{abstract}
Internal microbial infection may lead to abscesses formation in cattle. This study was conducted on 1500 slaughtered cattle from Mansoura abattoir and Damietta local dairy farms to screen out the presence of internal abscesses. Of 1500 slaughtered cattle, 160 animals $(10.67 \%)$ were affected with lung abscesses $(n=140)(87.5 \%)$, lung abscesses with tonsillar involvement $(n=3)(1.87 \%)$, liver abscesses $(n=15)(9.37 \%)$, bacterial endocarditis with systemic lodgment of bacterial emboli $(n=1)(0.62 \%)$ and spinal epidural abscess $(n=1)(0.62 \%)$. Younger animals less than 1 year were more susceptible. A variety of bacterial species including, Pasteurella multocida (P. multocida) 132 (70.58\%), Arcanobacterium pyogenes (A. pyogenes) 30 (16.04\%), Pseudomonas aeruginosa $12(6.41 \%)$, Staphylococcus aureus $8(4.27 \%)$ and Streptococcus spp. $5(2.67 \%)$ were isolated. The histopathological changes associated with the internal abscesses formation were described in this study. In conclusion, the frequency of bovine abscesses was the highest in lungs. The most common isolate was $P$. multocida followed by A. pyogenes.
\end{abstract}

Key words: Abscesses, Cattle, P. multocida, A. pyogenes, Histopathology.

\section{INTRODUCTION}

In addition to subcutaneous abscesses that are mostly infected by different species of zoonotic bacteria, abscesses may also develop in internal body organs such as the lungs or liver, if the organisms enter the blood stream (Gezon et al., 1991). The Corynebacterium, Staphylococcus, Streptococcus, Pasteurella spp., Escherichia coli, and other gram negative rods; Peptostreptococcus anaerobius and Eubacterium tortuosum were isolated in external and internal abscesses each in goats (Tadayon et al., 1980). Abscesses located in the internal organs caused considerable losses in production and variable mortality rates (Bekele, 1999). Generally, they are only detected after the animals are slaughtered, because even hundreds of small abscesses or several large abscesses rarely cause clinical manifestation (Nagaraja and Chengappa, 1998).

Liver abscesses in meat-producing animals represent a major factor that reduces the national income, either directly through condemnation of affected livers, or indirectly through effects on animal growth and production (Eid et al., 1998). Liver abscesses in

Corresponding author: Dr. WALAA F. AWADIN

E-mail address: walaafekriawadin@yahoo.com

Present address: Pathology Department, Faculty of Veterinary Medicine, Mansoura University slaughtered beef cattle result from aggressive grainfeeding programs (Nagaraja and Chengappa, 1998). The incidence, averaging from 12 to $32 \%$ in most feedlots, is influenced by a number of dietary and management factors. The primary etiologic agent was Fusobacterium necrophorum (F. necrophorum) followed by Actinomyces pyogenes (A. pyogenes). Generally, ruminal lesions resulting from acidosis were recognized as the predisposing factors for liver abscesses (Nagaraja and Chengappa, 1998).

The objectives of this study were to investigate the prevalence, etiological agents and gross and histopathological diagnosis of some recorded lesions slaughtered cattle. More information on such cases would be of direct interest to veterinarians and of comparative interest to medical bacteriologists.

\section{MATERIALS AND METHODS}

A total of 1500 cattle of varying ages, sexes and breeds (Holstein, cross breed) were slaughtered in Mansoura abattoir and Damietta local dairy farms over a period extending from January 2015 to January 2016. Cattle were categorized as calves (day 0 to 12 months of age) or adult (animals over 12 months of age). After postmortem examination, tissue specimens were collected from grossly affected 
organs and tissues containing abscesses including liver, lungs, tonsils, kidneys and spinal cord.

\section{Bacteriological examination}

A total of 166 samples were obtained from clinical specimens of internal lesions from 160 animals whereas, a single abscess was detected in 156 cattle and multiple abscesses in four cattle. The organ and tissue containing abscesses were flamed and a sterile blade was used to make a sharp incision in the lesion. Pus was collected and streaked on to plates containing 5\% sheep blood agar base and on MacConkey agar (Becton Dickinson, Sparks, USA) with an inoculation loop. The plates were incubated at $37^{\circ} \mathrm{C}$ for $24-48$ hours under aerobic and anaerobic conditions. A single colony from each plate was purified by sub-cultured. Gram-stain was used for assessment of bacterial morphology. The identification of isolates depends upon the colony morphological criteria, conventional biochemical characterization (catalase test, oxidase test, hemolysis on blood agar, growth on MacConkey agar and fermentation of sugar) and also subject bacterial identification automatically using VITEK 2 system (bioMérieux, Inc. Hazelwood, MO, USA), using commercial identification cards for Gram-positive and Gram-negative bacteria, in accordance to the manufacturer's recommendations.

\section{Histopathological examination}

Tissue specimens were then fixed in $10 \%$ neutral buffered formalin for histopathological evaluation according to standard techniques (Hewitson and Darby, 2010). Paraffin sections were cut at $5 \mu \mathrm{m}$ thickness, mounted on glass microscope slides and stained with hematoxylin and eosin (H\&E). Gross and histopathological lesions were recorded.

\section{RESULTS}

\section{Bacteriological Findings}

In this study, internal abscesses were detected in 160 $(10.67 \%)$ out of 1500 examined cattle at slaughter. A total of 186 organisms were isolated from the 166 samples collected from a total of 160 animals using the conventional cultural methods to determine the occurrence of different bacterial agents, Six different bacterial isolates were isolated including, $P$. multocida 132 (70.58\%), A. pyogenes 30 (16.04\%), Pseudomonas aeruginosa $12 \quad$ (6.41\%), Staphylococcus aureus $8(4.27 \%)$ and Streptococcus spp. $5(2.67 \%)$. However, of bacterial isolate $P$. multocida was most common isolate followed by $A$. pyogenes (Table 1).

\section{Gross and histopathological findings}

A-Lung abscesses were found in 140 cases (87.5\%). Pure colonies of $P$. multocida or A. pyogenes were detected in 113 young aged calves (1 month). Meanwhile, lungs with mixed bacterial infection were recognized in 27 older animals (aged 1-5 years) (Table 2). Lung abscesses with tonsillar involvement were recorded in 3 cases $(1.87 \%$ ) aged from 1 to 2 months; from which pure colonies of P. multocida were detected (Table 2). Grossly, lung abscesses were $0.5-2 \mathrm{~cm}$ in diameter enclosed by a thin or thick fibrous tissue capsule and contained a viscous whitecreamy or yellow odor-less mass (Fig. 1A-D). According to histopathological examination, lung abscesses were distinguished into two categories young and old. The young ones contained eosinophilic structure-less or homogenous material with multiple bacterial colonies in the center surrounded by thick zone of polymorphnuclers (PMNs) with some mononuclear cells (MNCs) and enclosed by connective tissue capsules. Suppurative exudate was seen filling pulmonary alveoli consisting of numerous neutrophils, desquamated alveolar epithelium, few macrophages and basophilic bacterial colonies (Fig. 2A-D). Meanwhile, older abscesses consisted of a homogenous eosinophilic mass focally displacing pulmonary parenchyma (Fig. 3A-D). Suppurative tonsillitis in 3 cases showed crypt abscesses containing eosinophilic structure-less or homogenous material and bacterial colonies with marked depletion of lymphoid follicles from lymphocytes. Dystrophic calcification occurred centrally in some of these abscesses (Fig. 4A-D).

B- Liver abscesses were recorded in 15 cases $(9.37 \%)$ aged from 1 month to 2 years, from which pure colonies of $A$. pyogenes were detected (Table 2). Grossly, liver abscesses were up to $15 \mathrm{~cm}$ diameter enclosed by a thick capsule and contained a viscous white-creamy purulent material (Fig. 5A\&B). Microscopically, pyogranulomatous nodules were noticed focally replacing hepatic parenchyma, consisting of central aggregation of PMNs followed by MNCs, epithelioid cells, multinucleated giant cells and surrounded by fibrous tissue capsule (Fig. 5C\&D).

C- In case of valvular endocarditis with systemic lodgment of bacterial emboli was seen in 1 case aged 3 years $(0.62 \%)$, from which pure colonies of $A$. pyogenes were detected (Table 2 ). Grossly, variable sizes of reddish growth were found on the valve leaflets (Fig. 6A) accompanied with generalized congestion and embolic inflammation in lungs, liver and kidneys. Microscopic examination showed bloody cyst containing bacterial colonies replaced the valve leaflet with formation of a pyogranulomatous nodule containing basophilic bacterial colonies (Fig. 6B-C). Septic emboli were also seen in kidneys, liver and lungs. Degeneration and necrosis of many renal tubular epithelial cells were noticed with presence of eosinophilic tubular casts. Liver in this case showed also few MNCs infiltration in portal areas (Fig. 7AD).

D- Spinal epidural abscess was found in 1 case $(0.62 \%)$ aged 2 years, from which pure colonies of $A$. 
pyogenes were detected (Table 2). Grossly, an encapsulated abscess of $8 \mathrm{~cm}$ diameter with necrotic liquefactive center was extended ventral to the T9T10 vertebral bodies (Fig. 8A). Microscopically, spinal epidural abscess revealed heavy aggregation of epithelioid macrophages, lymphocytes, neutrophils and few multinucleated giant cells were seen. Basophilic bacterial colonies and bony spicules were obvious inside the lesion. The neighboring segment of spinal cord showed severe axonal degeneration, demyelination of white fibers, neuronal necrosis and gliosis. Myelitis and meningitis was identified in the histologic section (Fig. 8B-D) and (Fig. 9A-D).

From the previous findings, the most common isolate was $P$. multocida and the second common isolate was A. pyogenes (Table 1). Young cattle less than 1 year were higher susceptible for internal microbial infection. In addition, abscesses were encountered in lungs more than other organs (Table 2).

Table 1: Prevalence of bacterial species involved in internal abscess in single infection and co-infection

\begin{tabular}{lccc}
\multicolumn{1}{c}{ Bacterial species } & Single & Co-infection & Total \\
\hline P. multocida & 105 & 27 & $132(70.58 \%)$ \\
\hline A.pyogenes & 28 & 2 & $30(16.04 \%)$ \\
\hline Streptococcus spp. & 0 & 5 & $5(2.67 \%)$ \\
\hline Pseudomonas aeruginosa & 0 & 12 & $12(6.41 \%)$ \\
\hline Staphylococcus aureus & 0 & 8 & $8(4.27 \%)$ \\
\hline Total & 133 & 54 & 187 \\
\hline
\end{tabular}

Table 2: Percentages and distribution of internal abscesses in cattle

\begin{tabular}{|c|c|c|c|c|}
\hline $\begin{array}{l}\text { Affected organ or } \\
\text { tissue }\end{array}$ & $\begin{array}{l}\text { Total no. of } \\
\text { cases }\end{array}$ & Age & Isolated bacteria & $\begin{array}{c}\text { No. }(\%) \\
\text { of isolates }\end{array}$ \\
\hline \multirow[t]{7}{*}{ lungs } & 140 & 1 month & P. multocida & 102 \\
\hline & & & A.pyogenes & 11 \\
\hline & & $1-5$ years & P. multocida + A. pyogenes & $\begin{array}{l}2 \\
5\end{array}$ \\
\hline & & & P. multocida + Streptococcus pyogenes & 12 \\
\hline & & & & 8 \\
\hline & & & P. multocida spp + Pseudomonas aeruginosa & \\
\hline & & & P. multocida + Staphylococcus aureus & \\
\hline Lungs\& tonsils & 3 & $1-2$ month & P. multocida & 3 \\
\hline liver & 15 & $\begin{array}{l}1 \text { month } \\
2 \text { years }\end{array}$ & A.pyogenes & 15 \\
\hline $\begin{array}{l}\text { kidney } \\
\text { endocardium } \\
\text { lungs } \\
\text { liver }\end{array}$ & 1 & 3 years & A.pyogenes & 1 \\
\hline $\begin{array}{l}\text { Spinal epidural } \\
\text { tissue }\end{array}$ & 1 & 2 years & A. pyogenes & 1 \\
\hline
\end{tabular}





Fig. 1 (A-C): Different gross appearance of lung abscesses in cattle A: Thin walled abscesses appear in dorsal aspect of apical lobe and cranio-ventral portion of diaphragmatic lobe (arrows). B: Thin walled abscesses appear in lowermost border of diaphragmatic lobe (arrows). C: Thick fibrous tissue encapsulated abscess appears in ventral aspect of diaphragmatic lobe (arrow). D: Cut section of lungs shows exudation of viscous creamy yellow pus material.
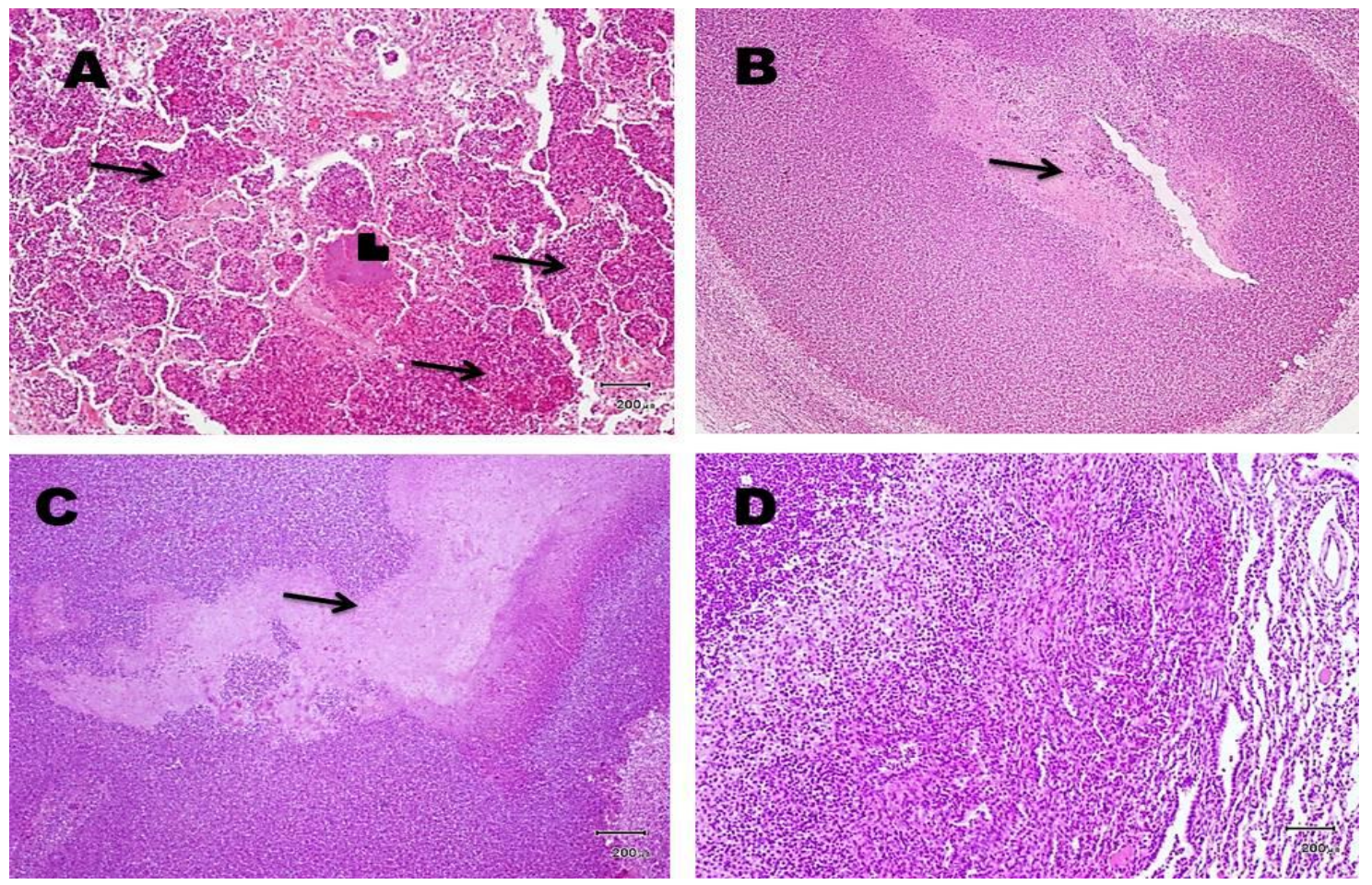

Fig. 2 (A-D): Lung microscopic picture shows different histological appearance of lung abscesses in cattle. A. Suppurative exudate is filling pulmonary alveoli consisting of numerous neutrophils (arrows) and basophilic bacterial colonies (arrowhead). B. Microscopic picture of young abscess shows eosinophilic homogenous material with multiple bacterial colonies in the center surrounded by thick zone of PMNs $\mathbf{C}$. High magnification of abscess in Fig. B to show central eosinophilic homogenous material (arrow). D. High magnification of abscess in Fig. B to show fibrous tissue capsule infiltrated with MNCs with collapsed adjacent alveoli. H\&E 

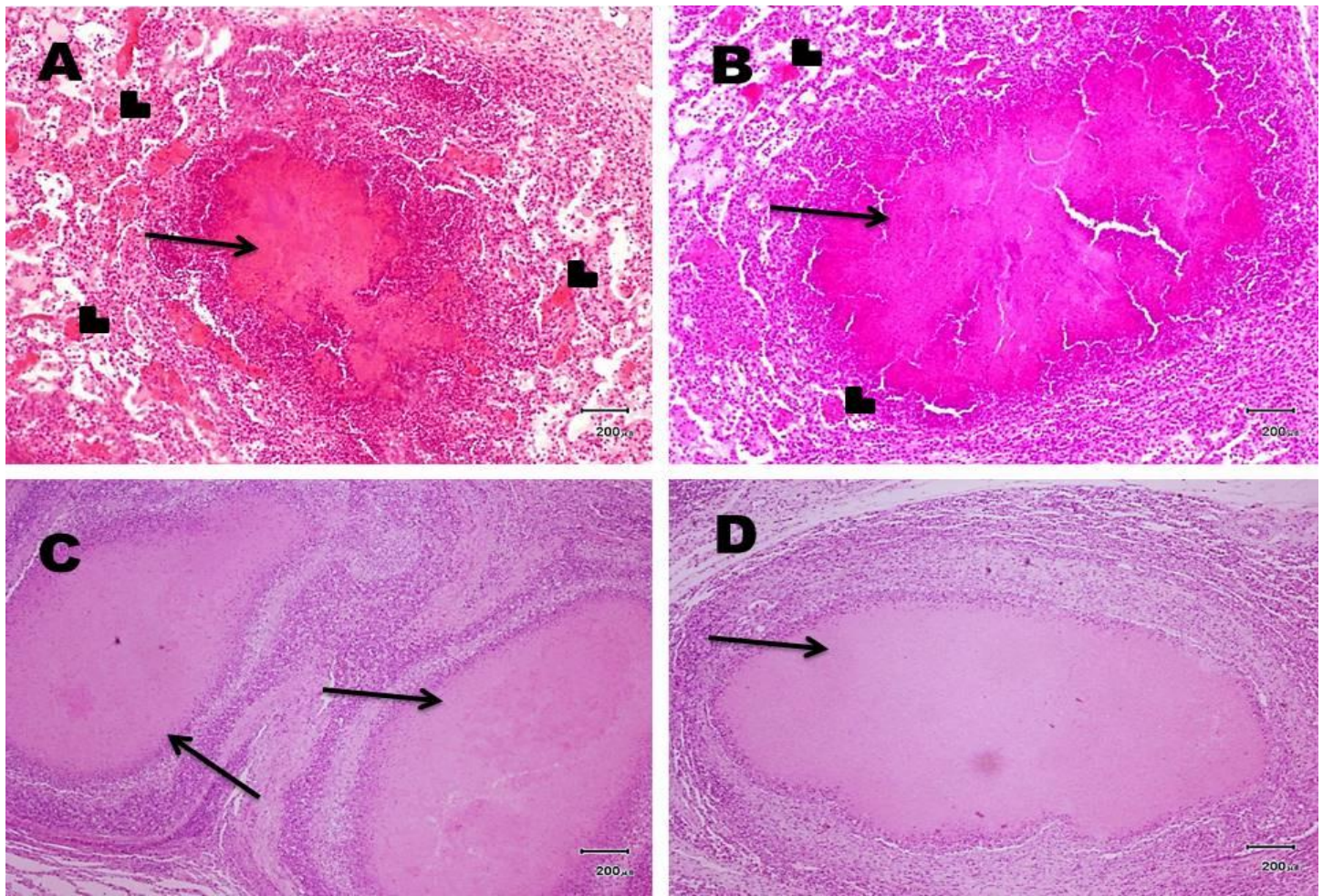

Fig. 3 (A-D): Lung microscopic picture shows microscopic picture of old abscesses. A\&B. shows focal eosinophilic homogenous material (caesated pus) surrounded by thin zone of PMNs and little fibrous tissue (arrows). Note the presence of similar material inside alveoli (arrowheads). C\&D. shows focal eosinophilic homogenous material (caesated pus) surrounded by alternating zones of PMNs and fibrous tissue (arrows). H\&E
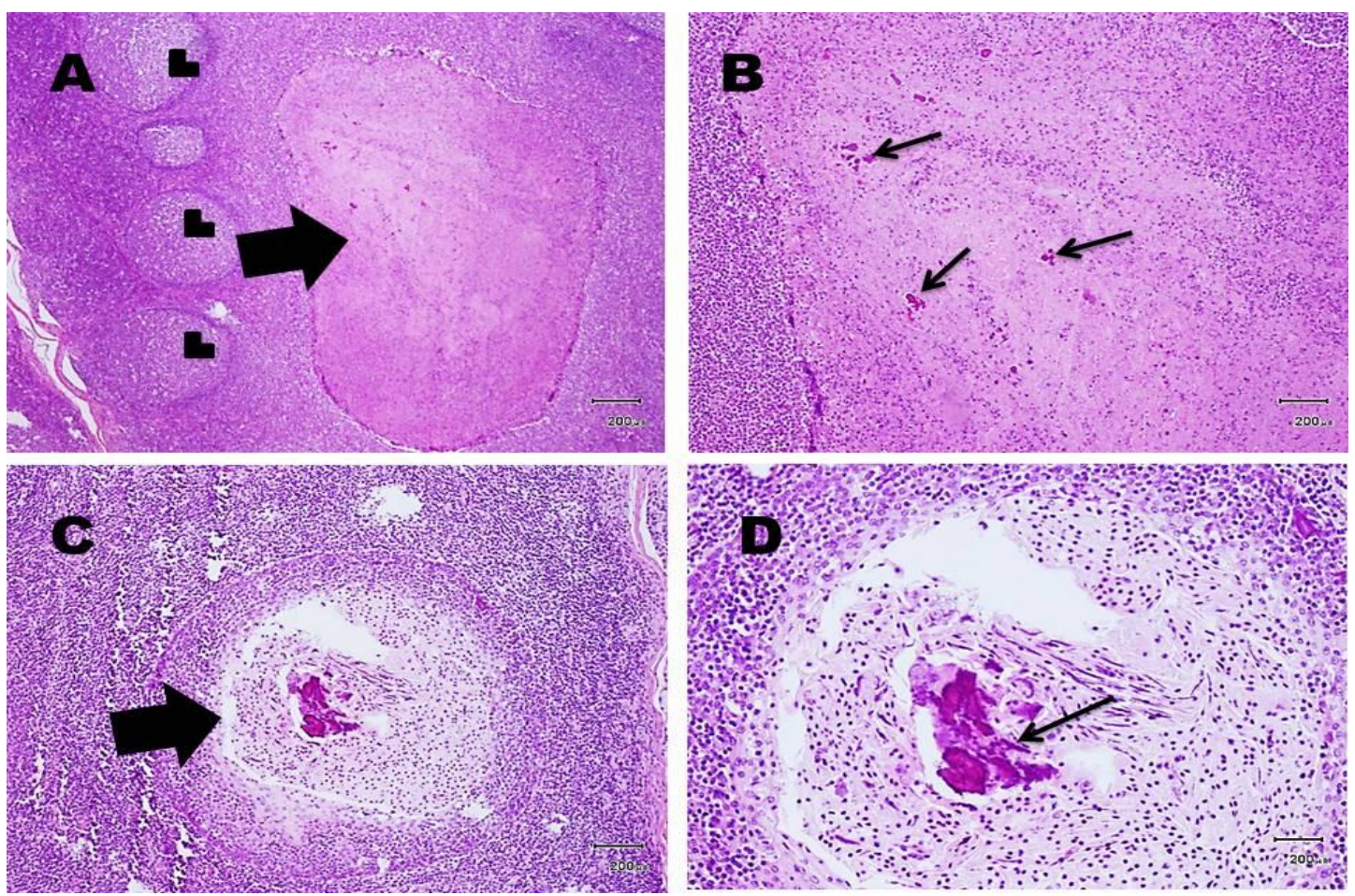

Fig. 4 (A-D): Tonsils microscopic picture shows A. Crypt abscess containing pus and bacterial colonies (thick arrow) with depleted lymphoid follicles (arrowheads). B. High magnification to show bacterial colonies (thin arrows). C. Crypt abscesses with central calcification (thick arrow) D. High magnification to show central calcification (thin arrow). H\&E. 

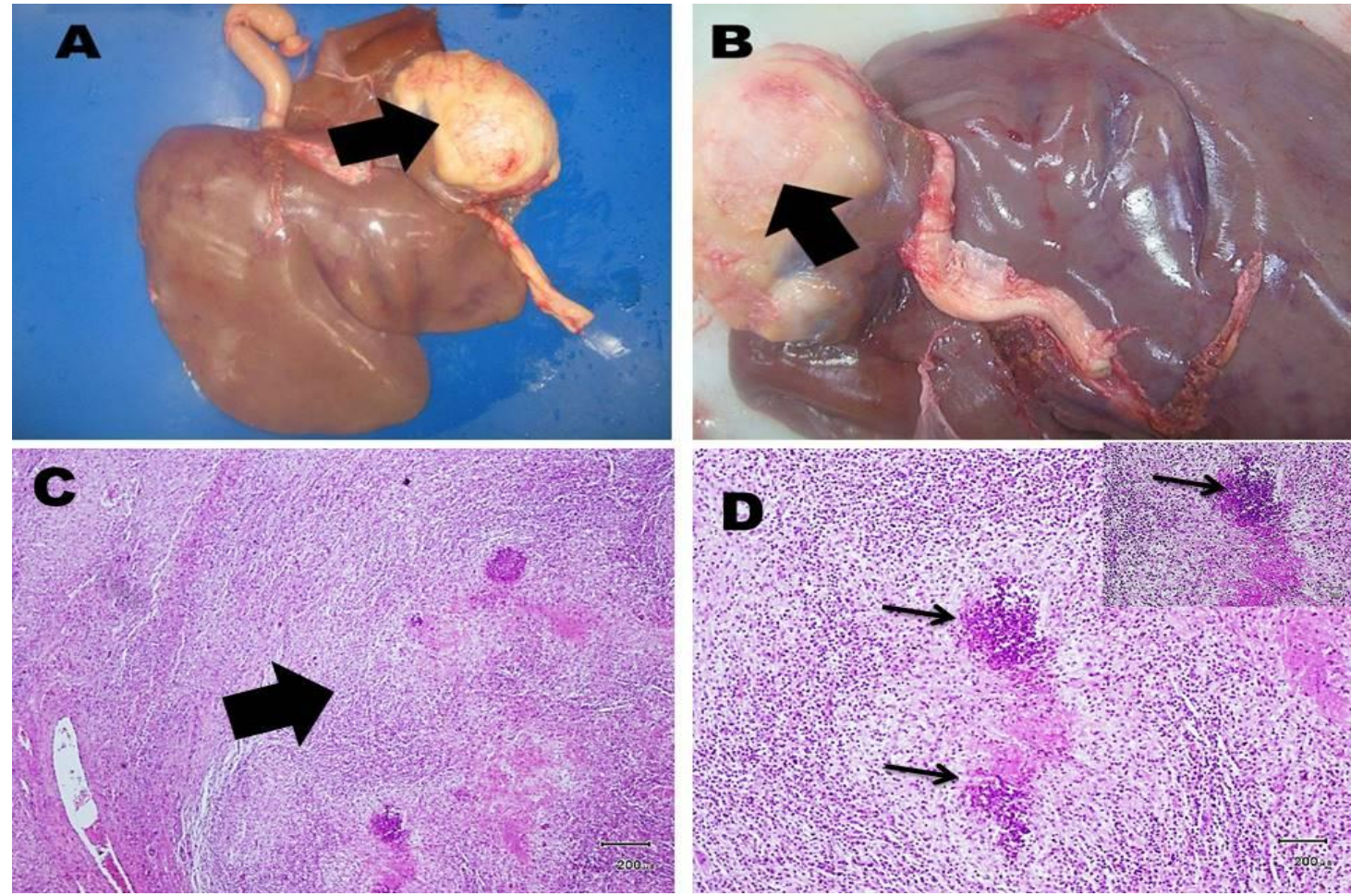

Fig. 5: A\&B. Gross appearance of liver abscesses in cattle (arrows). C. A pyogranulomatous nodule (thick arrow) consisting of central aggregation of PMNs followed by MNCs, epithelioid cells, multinucleated giant cells and surrounded by fibrous tissue capsule. D. High magnification to show central aggregation of PMNs (thin arrows). Insert. Higher magnification to show central aggregation of PMNs. H\&E
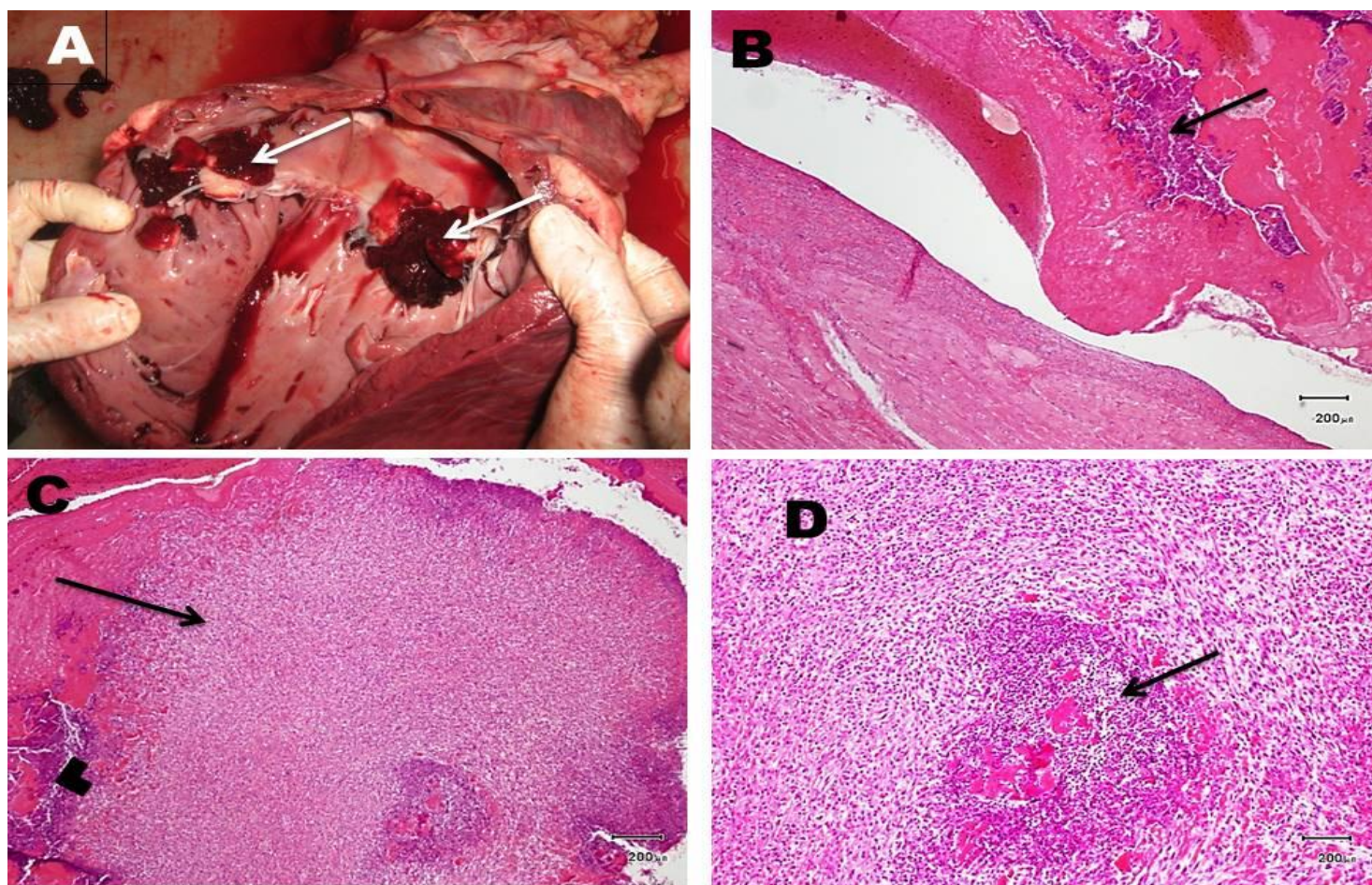

Fig. 6: A. Gross appearance of valvular endocarditis, variable sizes of reddish growth on the valve leaflets (white arrows). B. Bloody cyst containing basophilic bacterial colonies (arrow) is replacing valve leaflet. C. A pyogranulomatous nodule (arrow) consisting of central aggregation of PMNs followed by MNCs, epithelioid cells, multinucleated giant cells and surrounded by fibrous tissue capsule. Basophilic bacterial colonies can be seen (arrowhead). D. High magnification to show central aggregation of PMNs (thin arrow). H\&E 

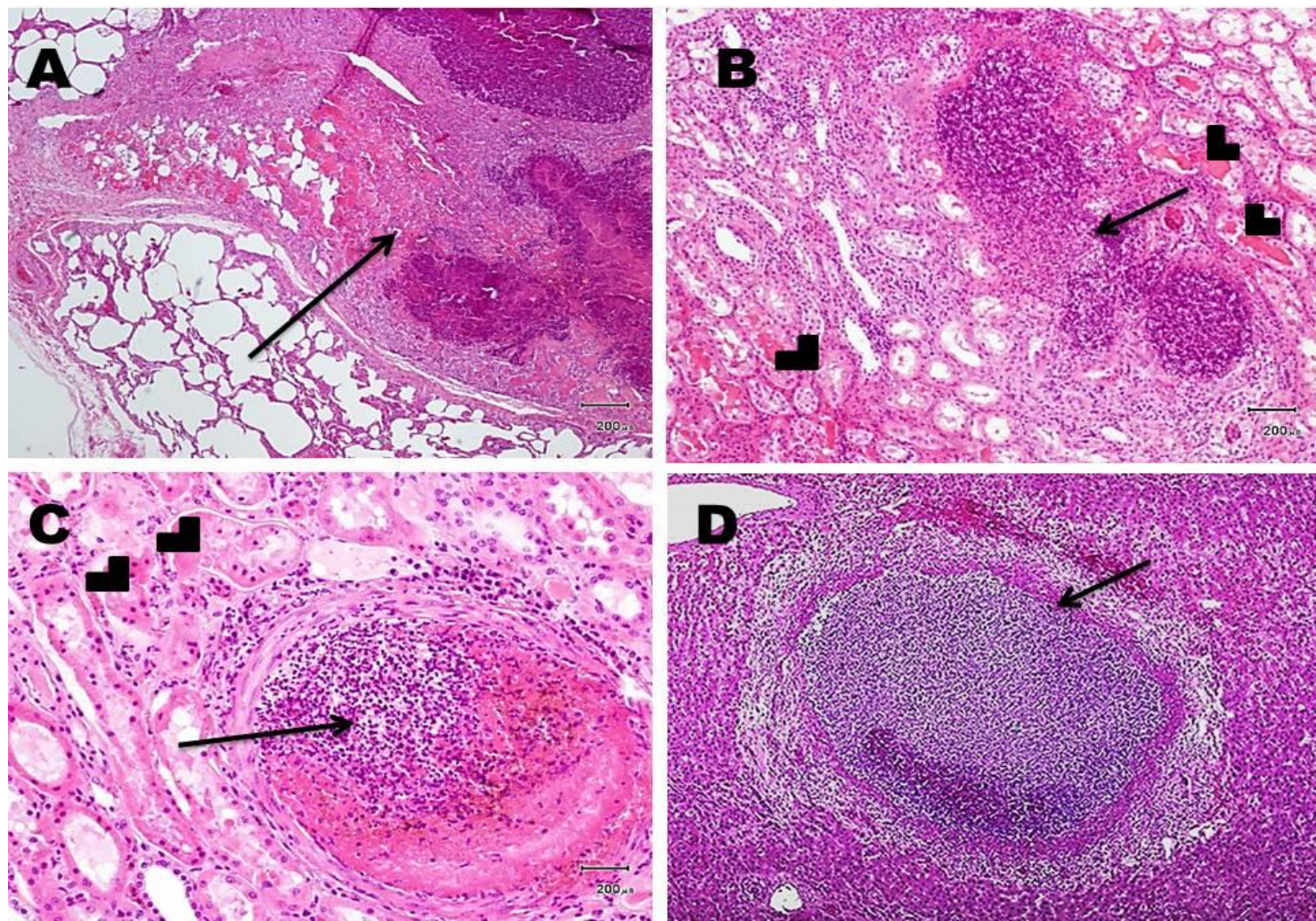

Fig. 7(A-D): Microscopic pictures showing septic emboli (arrows) in lungs (A), kidney (B\&C) and liver (D). Note the presence of eosinophilic tubular casts (arrowheads) in Fig. (B) and tubular necrosis (arrowheads) in Fig. (C) H\&E
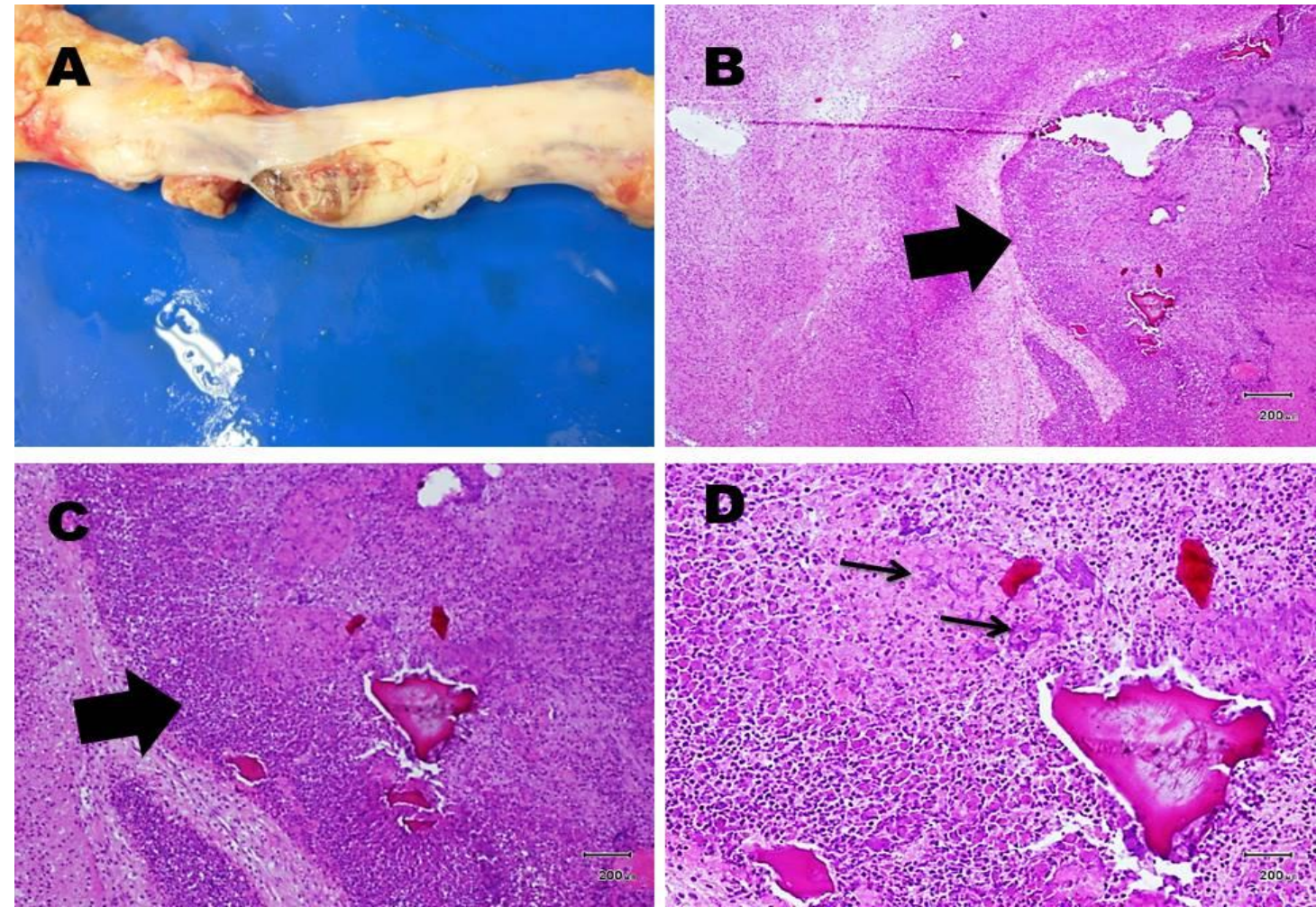

Fig. 8: A. Gross appearance of spinal epidural abscess (arrow). B\&C. A pyogranulomatous nodule (thick arrow) consisting of central aggregation of PMNs followed by MNCs, epithelioid cells, multinucleated giant cells and surrounded by fibrous tissue capsule. D. Higher magnification to show basophilic bacterial colonies (thin arrow). $\mathrm{H} \& \mathrm{E}$ 

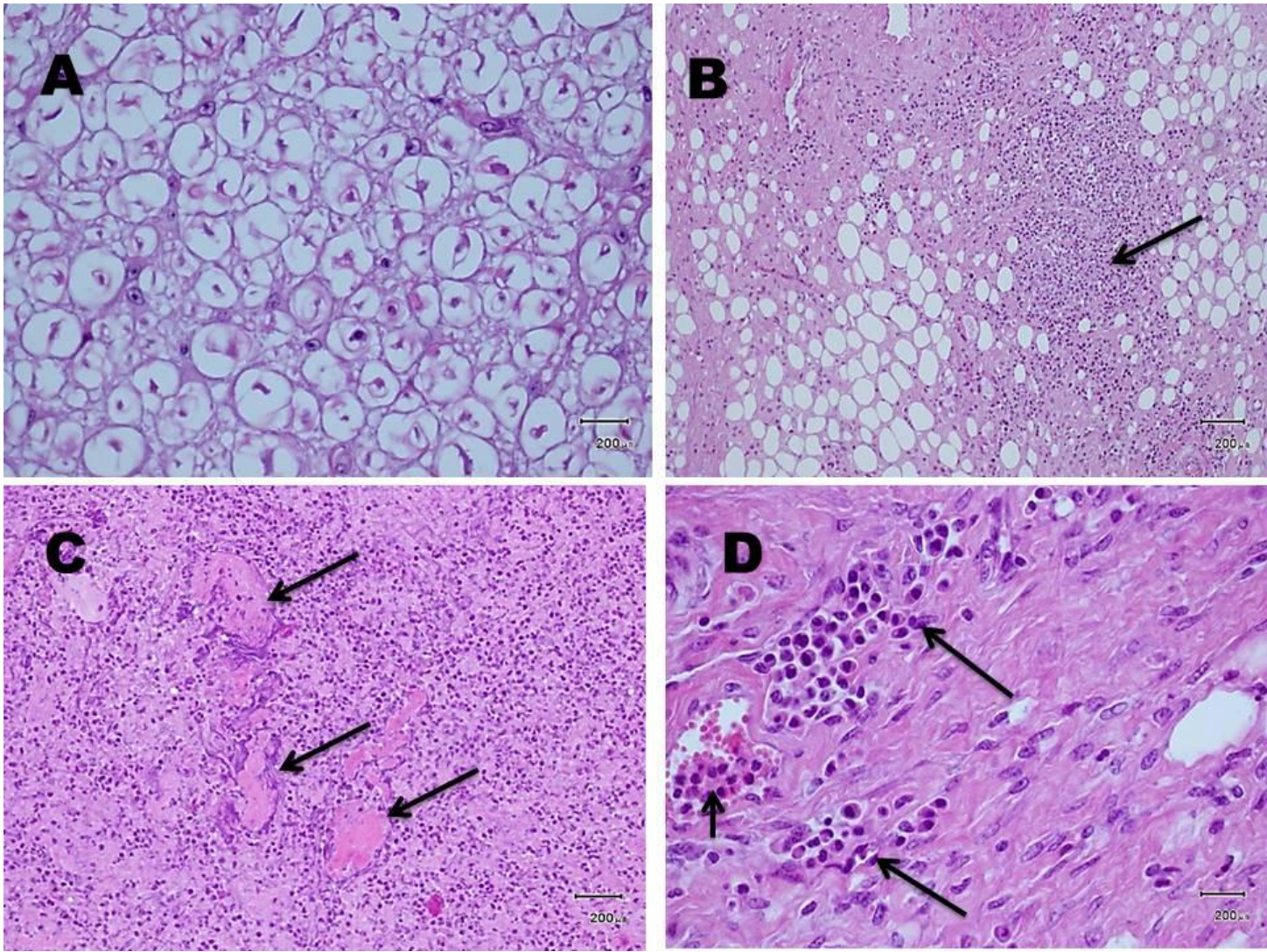

Fig. 9 (A-D): Spinal cord shows A. severe axonal degeneration, demyelination of white fibers, B. gliosis, C. myelitis, focal necrosis surrounded by basophilic bacterial colonies (arrows) and D. focal MNCs infiltration in dura mater (long arrows) blood vessel shows numerous leukocytic cells (short arrow). H\&E

\section{DISCUSSION}

Abscess is one of the major causes of organs and carcasses condemnation. Regassa et al. (2013) mentioned that the condemnation rate of liver, lung and heart due to abscess were $0.005 \%, 0.007 \%$ and $0.012 \%$, respectively in small ruminants. In our study, internal abscess was detected in $160(10.67 \%)$ out of 1500 examined cattle at slaughter. Also, Tadayon et al. (1980) detected internal abscess in 42 out a total of 86 abscesses in sheep and goat. In Japan, the incidence of abscesses in bovine lung, abdominal viscera (other than liver), muscle, bone and skin was generally lower than that in the liver. F. necrophorum was recovered in pure culture or was dominant in most of the lung, abdominal (other than hepatic) and hepatic abscesses examined. The second most common isolate was Corynebacterium pyogenes, which had high counts in some specimens (Kanoe et al., 1984). In the present study, the prevalence of abscesses was the highest in lungs. Our high prevalence rate could be attributed to environmental changes and husbandry practices, mixed herding and sharing of water and pasture with other animals. Higher distribution of the pyogenic infections among young calves suggested that the immune system of young animals is weaker than those adults, which make young animals more vulnerable to infection with pyogenic microorganisms (Devrajani et al., 2010).

In this study, out 186 bacterial isolates, $P$. multocida prevalence was $132(70.58 \%)$ and the most common bacteria isolated from lung abscess. $P$. multocida is a gram-negative bacterium found on the epithelium of the upper respiratory tracts in apparently healthy animals of several different species (Biberstein, 1990) and serotype A:3 is associated with severe suppurative bronchopneumonia in calves (Confer et al., 1996).

A. pyogenes a gram-positive, irregular, non-motile, non-spore forming bacterium that is one of the important opportunistic pathogens of the upper respiratory and genital tracts of cattle, sheep, swine, and many other species (Grohn et al., 2004 and Ertaş et al., 2005). A. pyogenes induces suppurative infections in the form of abscesses, empyemas, and pyogranulomas (Moore et al., 2010). In this study, $A$. pyogenes was isolated from lungs, liver and spinal epidural abscesses with a prevalence 30 (16.04\%). Lung abscesses were diagnosed at necropsy by Gezon et al. (1991) in 20 goats that most recently had 1 or more superficial abscesses. Abscess incidence was $27.6 \%$ (112 of 406) in wethers and $22.9 \%$ (154 of 687) in does. A. pyogenes was isolated most frequently by bacteriologic culture of abscess 
specimens and about 3 times as often as was Corynebacterium pseudotuberculosis or Staphylococcus sp, usually coagulase-positive $S$ aureus. Nagaraja et al. (1996) and Dore' et al. (2007) reported that the most common bacterium isolated from the liver abscess was A. pyogenes. One cause of liver abscesses is the entry, growth and establishment of pyogenic bacteria from rumen. The RFLP analysis of ribosomal genes (ribotyping) of A. pyogenes isolates from liver abscesses and the rumen has suggested that $A$. pyogenes, like $F$. necrophorum, originates from the rumen (Narayanan et al., 1998). The rumen is a natural environment for the pathogen and can be found not only in ingested contents, but also in the bacterial flora of the ruminal wall. Because A. pyogenes is a facultative anaerobe, it is more likely to be originated from the ruminal wall, where oxygen diffusing from capillaries is present in low concentrations in an otherwise anaerobic environment of the rumen (Nagaraja et al., 1996). Another cause of liver abscesses is the entry of pyogenic bacteria through the umbilical vein (only in newborns). Liver abscesses can occur at all ages and in all types of cattle, including dairy cows (Nagaraja and Lechtenberg, 2007). Moreover, abscesses involving the epidural space were rare; however, they represent a devastating neurosurgical emergency (Darouiche $e t$ al., 2006). In dogs, spinal epidural empyema was suspected by neurologic examination and spinal diagnostic imaging, but definitive diagnosis is made during surgery and by histopathology or necropsy. A definitive diagnosis of spinal epidural abscesses was confirmed by necropsy and during surgery in 2 calves (Zani et al. 2008). Cohen et al. (2015) concluded that cranial abscess infections in white-tailed deer were typically associated with $A$. pyogenes. The most common causative agents reported for spinal epidural empyema in dogs and for spinal epidural abscesses in humans include Staphylococcus and Streptococcus species (Darouiche et al., 1992; Dewey et al., 1998 and Darouiche et al., 2006). Recently, a case of vegetative valvular endocarditis was reported in one bovine calf in Malaysia as a sequel to navel ill due to E. coli infection (Adamu et al., 2014).

\section{CONCLUSIONS}

In this study, the prevalence of bovine abscesses was the highest in lungs. The incidence of infection was higher in young animals less than one year. The most common isolate was $P$. multocida and the second common isolate was $A$. pyogenes.

\section{ACKNOWLEDGMENTS}

We acknowledged departments of Pathology and Bacteriology, Faculty of Veterinary Medicine, Mansoura University, Egypt for support and supply of medias, instruments and devices.

\section{CONFLICT OF INTEREST}

We have no conflict of interest with any person or authority.

\section{REFERENCES}

Adamu, L.; Jesse, F.F.; Osman, A.Y.; Sabri, J.; Norsidin, M.J.; Zamri-Saad, M.; Haron, A.W. and Saharee, A.A. (2014): Vegetative valvular endocarditis in a calf: a clinical report. Res. Opin. Anim. Vet. Sci., 4(1), 1-4.

Bekele, T. (1999): Studies on respiratory disease "Sonbobe" in camels in eastern Ethiopia. Trop. Anim. Health Prod. 31: 333-345.

Biberstein, E.L. (1990): Our understanding of the Pasteurellaceae. Can. J. Vet. Res. 54: S78eS82.

Confer, A.W.; Nutt, S.H.; Dabo, S.M.; Panciera, R.J. and Murphy, G.L. (1996): Antibody responses of cattle to outer membrane proteins of Pasteurella multocida A:3. Am. J. Vet. Res. 57: $1453 \mathrm{e} 1457$.

Cohen, B.S.; Belser, E.H.; Keeler, S.P.; Yabsley, M.J. and Miller, K.V. (2015): Isolation and genotypic characterization of trueperella (arcanobacterium) pyogenes recovered from active cranial abscess infections of male whitetailed deer (odocoileus virginianus) J. Zoo Wildlife Med. 46(1): 62-67.

Darouiche, R.O. (2006): Spinal epidural abscess. N. Engl. J. Med. 355: 2012-2020.

Darouiche, R.O.; Hamill, R.J.; Greenberg, S.B.; Weathers, S.W. and Musher, D.M. (1992): Bacterial spinal epidural abscess. Review of 43 cases and literature survey. Medicine (Baltimore) 71:369-385.

Devrajani, K.; Abubakar, M.; Fazlani, A.S.; Shahid, F.; Ourban, A.S. and Imran, R. (2010): Occurrence and prevalence of bacterial species as identified from camel wound. Int. J. Agro Vet. Med. Sci. 4(4):96-104.

Dewey, C.W.; Kortz, G.D. and Bailey, C.S. (1998): Spinal epidural empyema in two dogs. J. Am. Anim. Hosp. Assoc. 34: 305-308.

Dore', E.; Fecteau, G.; He'lie, P. and Francoz, D. (2007): Liver Abscesses in Holstein Dairy Cattle: 18 Cases (1992-2003) J. Vet. Int. Med. 21: 853-856.

Ertaş, H.B.; Kilic, A.; Ozbey, G. and Muz, A. (2005): Isolation of Arcanobacterium (Actinomyces) pyogenes from abscessed cattle kidney and identification by PCR. Turk. J. Vet. Anim. Sci. 29:455-459.

Eid, R.M.; El-Mahdy, M.M.; Hamouda, M.A. and Fatam, M.D. (1998): Some studies on parasitic liver affections of camels in Egypt. Associ. Vet. Med. J. 38(76): 121-137.

Gezon, H.M.; Bither, H.D.; Hanson, L.A. and Thompson, J.K. (1991): Epizootic of external 
and internal abscesses in a large goat herd over a 16 - year period. J. Am. Vet. Med. Assoc. 15; 198: 257-63.

Grohn, Y.T.; Wilson, D.J.; Gonzalez, R.N.; Hertl, J.A.; Schulte, H.; Bennett, G. and Schukken, Y.H. (2004): Effect of pathogenspecific clinical mastitis on milk yield in dairy cows. J. Dairy Sci. 87: 3358-3374.

Hewitson, T.D. and Darby, I.A. (2010): Histology Protocols. Histopathological examination Humana, Press. p. 229-340.

Kanoe, M.; Nouka, K. and Toda, M. (1984): Isolation of obligate anaerobic bacteria from bovine abscesses in sites other the liver. Med. Microbiol.18, 365-369.

Moore, R.; Miyoshi, A.; Pacheco, L.G.C.; Seyffert, N. and Azevedo, V. (2010): Corynebacterium and Arcanobacterium. In: Gyles CL, Prescott JF, Songer JG, Theon CO (eds.). Pathogenesis of bacterial infections in animals. 4th ed. Ames (IA): Wiley-Blackwell. p. 113-147.

Nagaraja, T.G. and Lechtenberg, K.F. (2007): Liver abscesses in feedlot cattle. Vet. Clin. Food Anim. 23: 351-369.

Nagaraja, T.G. and Chengappa, M.M. (1998): Liver abscesses in feedlot cattle: a review. J. Anim. Sci. 76(1): 287-98.

Nagaraja, T.G.; Laudert, S.B. and Parrott, J.C. (1996): Liver abscesses in feedlot cattle. Part I. Causes, pathogenesis, pathology and diagnosis.
Compendium on Continuing Education for the Practicing Veterinarian, 18: S230-41.

Narayanan, S.; Nagaraja, T.G.; Wallace, N.; Staats, J.; Chengappa, M.M. and Oberst, R.D. (1998): Biochemical and ribotypic comparison of Actinomyces pyogenes and A. pyogenes-like organisms from liver abscesses, ruminal wall, and ruminal contents of cattle. Am. J. Vet. Res. 59: 271-276.

Quinn, P.J.; Carter, M.; Dnnelly, C.J. and Leonard, C.F. (2002): Veterinary Microbiology and Microbial diseases $1^{\text {st }}$ Ed. London: Great Britain, Blackwell science. pp. 21-218.

Regassa, A.; Moje, N.; Megersa, B.; Beyene, D.; Sheferaw, D.; Debela, E.; Abunna, F. and Skjerve, E. (2013): Major causes of organs and carcass condemnation in small ruminants slaughtered at Luna Export Abattoir, Oromia Regional State, Ethiopia. Prevent. Vet. Med. 110, (2): 139-148.

Tadayon, R.A.; Cheema, A.H. and Muhammed, S.I. (1980): Microorganisms associated with abscesses of sheep and goats in the south of Iran, Am. J. Vet. Res. May; 41:798-802.

Zani, D.D.; Romano, L.; Scandella, M.; Rodena, M.; Riccaboni, P.; Morandi, N.; Lombardo, R.; Di Giancamillo, M.; Belloli, A.G. and Pravettoni, D. (2008): Spinal Epidural Abscess in Two Calves. Vet Surg 37; 801-808.

\section{دراسات باثولوجية وبكتيرولوجية على بعض الخراريج الداخلية المسجلة فى الابقار المذبوحة ولاءء عوضين ، (مل عبد الستار Email: walaafekriawadin@yahoo.com
Assiut University web-site: www.aun.edu.eg}

\footnotetext{
تؤدى العدوى الميكروبية الداخلية الى تكوين خراريج في الابقار. ولذلك كان الهدف من هذه الدراسة تحديد تكرار واسباب تكوين

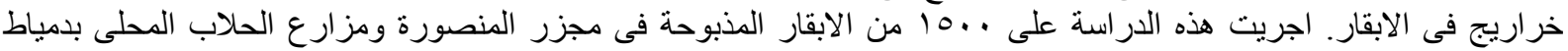

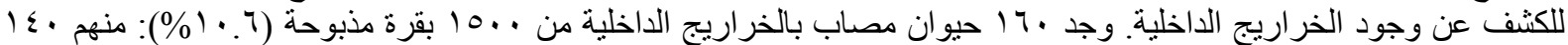

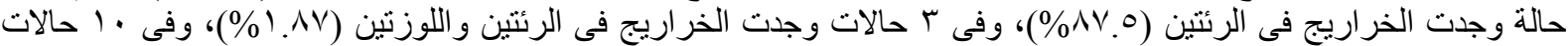

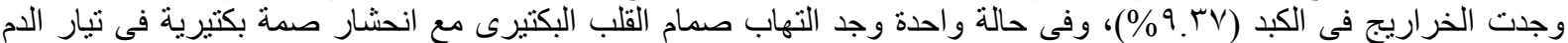

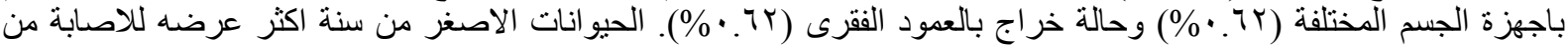

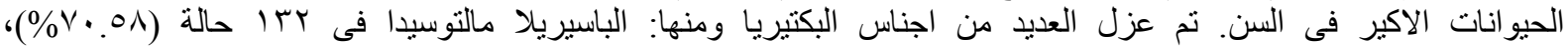

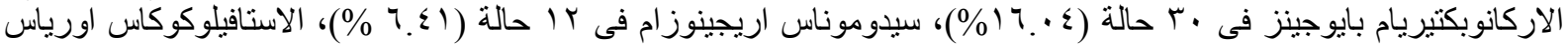

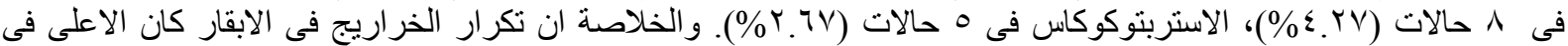

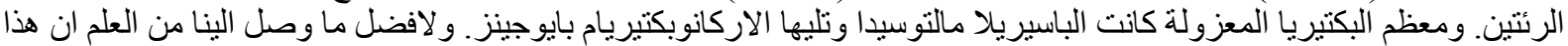

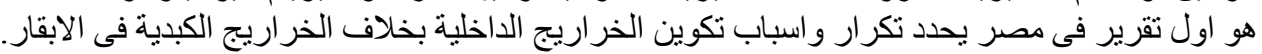

